\title{
The Effect of Profitability, Capital Structure, Company Size, and Dividend Policy on Company Value on the Indonesia Stock Exchange
}

Titik Purwanti

Universitas Widya Dharma Klaten, Indonesia Corresponding email: titik@unwidha.ac.id

\begin{abstract}
:
Every company, especially companies that have gone public have value. The value that is owned by the company is a perception that comes from investors to the level of achievement of the success of a company in managing various resources that are controlled and owned which is reflected in the stock price of the company in the market. This study aims to determine the effect of profitability, capital structure, company size, and dividend policy on firm value. The companies in this study are manufacturing companies listed on the Indonesian stock exchange during the period of 2015 to 2018. The population of this research is all manufacturing companies listed on the Indonesian stock exchange in 2015-2018. The research sample of 11 companies. The technique used in the sampling of this study used a purposive sampling technique. In this study secondary data was obtained from the Indonesian Capital Market Directory. Data analysis techniques using descriptive statistics and testing using the classic assumption test. Testing the research hypothesis using multiple linear regression test, simultaneous test ( $F$ test), partial test (t test), and coefficient of determination test (R2 test). The results showed that simultaneous profitability, capital structure, company size, and dividend policy significantly influence the value of manufacturing companies. Partially, profitability has a positive and significant effect on firm value, capital structure has a positive and significant effect on firm value, company size has a negative and significant effect on firm value, and dividend policy has positive and not significant effect on firm value.
\end{abstract}

Keywords:

profitability, capital structure, company size, dividend policy, firm value

JEL: A10, H0O, H10, H19

\section{INTRODUCTION}

The company in order to gain the trust of investors requires hard work, especially in building good value for the company. Every company, especially companies that have gone public have value. The value owned by the company is a perception that comes from investors to the level of achievement of the success of a company in carrying out various management of the resources it controls and has reflected in the stock prices of these companies in the market. Every company that has a great desire to develop is always required to increase its value in order to maintain long-term survival in the midst of the advancement of IT globalization in the industrial era 4.0 towards industry 5.0 and to maintain its investors, namely the investors who helped build the company, especially in terms of capital included. The value of the company is the perception of investors on the level of success of a company in managing the company's resources which is reflected in its share price. But in general, companies are not only required to achieve maximum profits, but are also expected to be able to prosper shareholders and increase the value of the company. One of the main objectives of the company is to increase the value of the 
company (Sudana, 2011). Company value is the investor's perception of the company's success rate related to stock prices (Sujoko \& Soebiantoro, 2007). Maximizing the value of the company is the same as maximizing the present value of cash flows or revenue streams that are expected and received by investors in the future (Sudana, 2011). There are several factors that can affect a company's value, including: company growth, capital structure and profitability. The company's growth is a change (can decrease or can also increase) in total assets of the company which last year asset growth illustrates the profitability will come and the growth that comes (Taswan, 2003).

Capital structure is the proportion of funding with company debt. Thus, debt is an element of the capital structure that is the key to improving profitability and company performance. The third factor that can affect the value of a company is profitability. Profitability is defined as the company's ability to generate profits and measure the level of operational efficiency and efficiency in using its assets (Chen, 2004). Capital structure is a balance of the amount of short-term debt that is permanent, long-term debt, preferred shares and ordinary shares (Sartono, 2011). The capital structure is the company's long-term permanent funding mix as indicated by debt, preferred stock and common stock equity (Wachowicz, 2007). The importance of capital structure for each company because it has a direct effect on the financial position of the company so that financial managers must know the factors that influence the capital structure in order to maximize the prosperity of the company's shareholders or investors (Yuliani, 2012).

Decisions concerning investment will determine the source and form of funds for financing. The amount of debt and own capital, and how the types of debt and capital will be used, bearing in mind the financing structure will determine the cost of capital that will be the basis for determining the desired required return. Investors have the main objective to improve welfare by expecting returns in the form of dividends and capital gains, while companies expect continuous growth to maintain their survival while at the same time providing welfare to their shareholders, so that dividend policy is important to meet shareholders' expectations of dividends by not impeding the growth of the company on the other hand.

The size of the company is one factor that is also able to influence the value of the company. Companies that have a large size tend to be able to face economic competition because they have better management or control, making them less vulnerable to economic fluctuations (Fau, 2015). The size of a company can be measured by the total assets owned. The greater the total assets of a company, the greater the size of a company.

\section{THEORITICAL REVIEW}

\section{Profitability}

Company profitability is one way to assess precisely the extent of the returns to be obtained from investment activities. Profitability according to Saidi (2004) is the company's ability to make a profit. Profitability according to Harahap (2007), Tho'in (2020) is the ability to generate profits during a certain period by using assets or capital, both overall capital and own capital. Profitability is the ability of a company to generate profit for a certain period. Profitability is also an indicator of the performance of a management in managing the wealth of a company in the form of profits generated (Tho'in \& Prastiwi, 2019); (Riyanto, 2011); (Nuryanto, et., al, 2014). 


\section{Capital Structure}

Capital structure is the proportion of funding with company debt. Companies with a large level of business developers will require a large source of funding, so additional funds are needed from external parties in an effort to increase funding requirements in the business development process. Companies with a good level of business development in the long run will provide large profits to investors. This will have an impact on increasing the value of the company. According to Halim (2007), what is meant by capital structure is the balance of the amount of short-term debt that is fixed, long-term debt, preferred shares, and ordinary shares. Keown et al (2010) said that the capital structure is the ratio or balance of long-term funding of the company aimed at the comparison of long-term debt to sources of capital. According to Husnan and Pudjiastuti (2006) the best capital structure is a capital structure that can maximize the value of the company or the price of shares, so that companies that have a good capital structure will be able to increase the value of the company.

Capital structure measured by debt to equity ratio (DER) is a comparison of the total debt held by the company with the company's total equity. The unit of measurement of DER is in percentage. Total debt is total liabilities (both short-term and long-term debt). While the total stakeholder's equity is the total equity capital owned by the company. The higher the DER, it will show the composition of total debt is greater than the total own capital, so that the greater the company's burden on creditors (Robert, 1997).

\section{Company Size}

The size of the company is a reflection of the total assets owned by the company. The greater the size of the company, it means that the assets owned by the company are also getting bigger and the funds needed by the company to maintain its operational activities are increasing. The greater the size of the company will affect management decisions in deciding what funding will be used by the company so that funding decisions can optimize the value of the company. The size of the company is considered able to influence the value of the company. The size of the company can be seen from the total assets owned by one company. The large size of the company reflects that the company is experiencing good growth and growth thereby increasing the value of a company. Increasing company value can be indicated by the total assets of the company that has increased and is greater than the amount of company debt.

\section{Dividend Policy}

Dividends are the distribution of a portion of a company's profits to shareholders. The amount of this dividend can affect stock prices. If the dividend paid is high, then the share price tends to be high so the value of the company is also high, conversely, if the dividend paid is small, then the company's share price is also low. The ability to pay dividends is closely related to the company's ability to make a profit. If the company gets a large profit, then the ability to pay dividends is also large. Sartono (2011) states that dividend policy is a decision whether the profits obtained by the company will be distributed to shareholders, or will be retained in order to fund investment in the future. Sugiono (2009) explains that dividends are company revenue distributed to shareholders. Dividends are the distribution of profits provided by the issuing company of the profits generated by the company. Dividend Payout Ratio (DPR) or Dividend Payment Ratio is a ratio that shows the percentage of each profit obtained that is distributed to shareholders in cash. 


\section{The value of the company}

Company value is the price that prospective buyers are willing to pay if the company is sold. The higher the value of the company, the greater the prosperity that will be received by the owner of the company (Husnan \& Eny, 2006). Company value is an investor's perception of the level of success of the company in managing resources that is reflected in the company's stock price. The higher the stock price the higher the value of the company, conversely the lower the stock price, the company value is also low or the company's performance is not good. In making financial decisions, financial managers need to determine the objectives to be achieved. The right financial decision can maximize the value of the company so that it can increase the prosperity of the company owner. Soliha \& Taswan (2002) states that the higher the stock price means the higher the value of the company. High company value is the desire of the owners of the company, because with a high value shows the prosperity of shareholders is also high. To achieve this, the company expects financial managers to do the best for the company by maximizing the value of the company so that the prosperity (welfare) of owners or shareholders can be achieved (Suad, 2005)

\section{RESEARCH METHOD}

The approach used in this research is a quantitative approach. The population in this study are all manufacturing companies listed on the Indonesian stock exchange according to the study period, namely 2015-2018. The sample in this study was 11 companies in which the sampling technique used purposive sampling technique. Research data is secondary data obtained from the Indonesian Capital Market Directory. The data analysis technique used is descriptive statistical analysis and classic assumption test by testing the hypothesis using multiple linear regression test, $F$ test, $t$ test, and $R^{2}$ test.

\section{RESULTS AND DISCUSSION}

\section{Multiple Linear Regression Test}

Table 1. Multiple Linear Test Results Coefficients $^{\text {a }}$

\begin{tabular}{|l|r|r|r|r|r|}
\hline \multirow{2}{*}{ Model } & \multicolumn{2}{|c|}{ Unstandardized Coefficients } & $\begin{array}{c}\text { Standardized } \\
\text { Coefficients }\end{array}$ & \multirow{2}{*}{$\mathrm{t}$} & \multirow{2}{*}{ Sig. } \\
\cline { 2 - 4 } & \multicolumn{1}{|c|}{$\mathrm{B}$} & Std. Error & \multicolumn{1}{c|}{ Beta } & & \\
\hline 1 (Constant) & 22,492 & 10,767 & & 2,089 & 0,043 \\
Return on Equity & 0,147 & 0,038 & 0,280 & 3,832 & 0,000 \\
Debt to Equity Ratio & 21,108 & 2,213 & 0,738 & 9,539 & 0,000 \\
Size & $-2,097$ & 0,646 & $-0,195$ & $-3,244$ & 0,002 \\
Dividend Payout Ratio & 0,025 & 0,036 & 0,040 & 0,662 & 0,512 \\
\hline
\end{tabular}

a. Dependent Variable: Price to Book Value

From the regression equation in the explanation of table 1 it can be explained that the constant coefficient value of 22.492 has meaning if all independent variables are assumed to be equal to zero (0), then $\mathrm{Y}$ is 22.492 .

This means that if $\operatorname{ROE}\left(\mathrm{X}_{1}\right)$, $\operatorname{DER}\left(\mathrm{X}_{2}\right)$, Size $\left(\mathrm{X}_{3}\right)$, and $\operatorname{DPR}\left(\mathrm{X}_{4}\right)$ are zero, then the company's value will increase by 22.492 . The greater the value of the regression coefficient 
of the independent variables financial and non-financial research shows the greater influence of the independent variables of the study on the dependent variable. ROE coefficient $\left(X_{1}\right)$ of 0,146 has the meaning that the variable ROE $\left(X_{1}\right)$ has a positive relationship to the value of the company which means that if ROE increases by 1 unit, the value of the company will increase by 0.147 assuming that the independent variable others are constant. Thus, the higher the ROE, the higher the value of the company. The DER coefficient $\left(X_{2}\right)$ of 21,108 has the meaning that the DER variable $\left(X_{2}\right)$ has a positive relationship to the value of the company which means that if the DER increases by 1 unit, the value of the company will increase by 21.108 assuming that the other independent variables constant. Thus, the higher the DER, the higher the value of the company. The Size $\left(X_{3}\right)$ coefficient of -2.097 has the meaning that the Size $\left(X_{3}\right)$ variable has a negative relationship with the value of the company, which means that if Size increases by 1 unit, the value of the company will decrease by 2.097 assuming that the independent variable the others are constant. Thus, the higher the Size, the lower the value of the company. The coefficient of Parliament $\left(X_{4}\right) 0.025$ has the meaning that the House of Representatives $\left(\mathrm{X}_{4}\right)$ have a positive relationship to the value of the company which means that if Parliament is increased by 1 unit, the value of the company will rise by 0.025 assuming that the other independent variables constant. Thus, the higher the DPR, the higher the value of the company.

\section{F test}

Table 2. Test Results F

ANOVA $^{\text {b }}$

\begin{tabular}{|ll|r|r|r|r|r|}
\hline \multicolumn{1}{|c|}{ Model } & Sum of Squares & df & Mean Square & F & Sig. \\
\hline 1 & Regression & 12924,561 & 4 & 3231,140 & 73,369 & $0,000^{\circ}$ \\
Residual & 1717,560 & 39 & 44,040 & & \\
Total & 14642,122 & 43 & & & \\
\hline
\end{tabular}

a. Predictors: (Constant), ROE, Dept to Equity Ratio, Size, DPR

b. Dependent Variable: Price to Book Value

Based on the explanation in the above table, it is known that the significance value for the effect of $X_{1}, X_{2}, X_{3}, X_{4}$ simultaneously on $Y$ is $0,000<0.05$ and the calculated $F$ value is $73.396>\mathrm{F}$ table 2.61, so it can be concluded that $\mathrm{H}_{1}$ is accepted, which means simultaneously profitability (ROE), capital structure (DER), company size and dividend policy (DPR) have a significant effect on firm value.

\section{T test}

Table 3. $\mathrm{t}$ Test Results

Coefficients $^{\text {a }}$

\begin{tabular}{|l|r|r|r|r|r|}
\hline \multirow{2}{*}{ Model } & \multicolumn{2}{|c|}{$\begin{array}{c}\text { Unstandardized } \\
\text { Coefficients }\end{array}$} & $\begin{array}{c}\text { Standardized } \\
\text { Coefficients }\end{array}$ & \multirow{2}{*}{$\mathrm{t}$} & \multirow{2}{*}{ Sig. } \\
\cline { 2 - 4 } & \multicolumn{1}{|c|}{$\mathrm{B}$} & Std. Error & \multicolumn{1}{c|}{ Beta } & & \\
\hline 1 (Constant) & 22,491 & 10,767 & & 2,089 & 0,043 \\
& 0,146 & 0,038 & 0,280 & 3,832 & 0,000 \\
Return on Equity & 21,107 & 2,213 & 0,738 & 9,539 & 0,000 \\
Debt to Equity Ratio & $-2,096$ & 0,646 & $-0,195$ & $-3,244$ & 0,002 \\
Size & 0,024 & 0,036 & 0,040 & 0,662 & 0,512 \\
\hline
\end{tabular}

a. Dependent Variable: Price to Book Value 
Based on Table 3 above, that: The significance value of the variable ROE $\left(X_{1}\right)$ of 0,000 $<0.05$ and $t_{\text {count }} 3,832>t_{\text {table }} 2,02269$, so it can be concluded that partially there is a significant influence of profitability (ROE) on the value of the company in manufacturing companies listed on the Indonesia Stock Exchange in 2015-2018, at a significance level of $5 \%$. The significance value of the DER variable $\left(X_{2}\right)$ is $0,000<0.05$ and $t_{\text {count }} 9.539>t_{\text {table }}$ 2.02269 , so it can be concluded that partially there is a significant influence of capital structure (DER) on the value of the company in manufacturing companies listed on the Indonesia Stock Exchange in 2015-2018, at a significance level of 5\%. The significance value of the variable Size $\left(X_{3}\right)$ was $0.02<0.05$ and $t-3.244<t_{\text {table }} 2.02269$, so it can be concluded that partially a negative and significant effect of firm size on firm value in manufacturing companies registered at Indonesia Stock Exchange in 2015-2018, at a significance level of $5 \%$. The significance value of the variable DPR $\left(X_{4}\right)$ of $0.512>0.05$ and $t_{\text {count }} 0.662<t_{\text {table }} 2.02269$, so it can be concluded that partially a positive and insignificant effect of dividend policy (DPR) to the value of companies in manufacturing companies listed on the Indonesia Stock Exchange in 2015-2018, at a significance level of 5\%.

Test $\mathbf{R}^{2}$

Table 4. $\mathrm{R}^{2}$ Test Results

Summary Model $^{\mathrm{b}}$

\begin{tabular}{|l|l|r|r|r|}
\hline Model & $\mathrm{R}$ & \multicolumn{1}{|c|}{ R Square } & Adjusted R Square & Std. Error of the Estimate \\
\hline 1 & $0,940^{\mathrm{a}}$ & 0,884 & 0,872 & 6,63627 \\
\hline
\end{tabular}

a. Predictors: (Constant), ROE, Debt to Equity Ratio, Size, DPR

b. Dependent Variable: Price to Book Value

Based on the results of the coefficient of determination test it is known that the coefficient of determination ( $R$ - square is 0,884 which means the profitability variable (ROE), capital structure (DER), company size (SIZE), and dividend policy (DPR) have a close relationship with the variable PBV of $88.4 \%$. While the Adjusted R-square value of 0,872 . This value can be interpreted that the variable profitability (ROE), the capital structure (DER), firm size (SIZE), and the dividend policy (DPR) is able to influence / explain PBV simultaneously or jointly by $87,20 \%$ is equal to $12,80 \%$ is influenced by other factors not explained in this study.

\section{CONCLUSION}

The results showed that simultaneous profitability, capital structure, company size, and dividend policy significantly influence the value of manufacturing companies. Partially, profitability has a positive and significant effect on firm value, capital structure has a positive and significant effect on firm value, company size has a negative and significant effect on firm value, and dividend policy has positive and not significant effect on firm value.

\section{BIBLIOGRAPHY}

Agus Sartono. (2011). Manajemen Keuangan Teori dan Aplikasi. Yogyakarta: BPFE.

Chen, Li Yueh, (2004). "Examining The Effect OfOrganization Culture And Leadership Behaviors On Organizational Commitment, Job Satisfaction, Adan Job Performance At Small And Middle-Sized Firma Of Taiwan". Journal of American Academy of Business. 
Fau. (2015). Pengaruh Struktur Modal, Pertumbuhan Perusahaan, Ukuran Perusahaan dan Profitabilitas Terhadap Nilai Perusahaan Pada Perusahaan Manufaktur Yang Terdaftar

Di Bursa Efek Indonesia. Skripsi.

Halim. (2007). Manajemen Keuangan Bisnis. Bogor: Ghalia Indonesia.

Harahap. (2007). Analisa Kritis Atas Laporan Keuangan. Jakarta: Raja Grafindo Persada.

Husnan, \& Eny. (2006). Dasar-Dasar Manajemen Keuangan. Jakarta: UPP STIM YKPN.

Husnan, S \& Enny P. (2006). Dasar-Dasar Manajemen Keuangan. Edisi Kelima. UPP STIM YKPN: Yogyakarta.

Keown, A. J., David F. Scott, J., Martin, J. D., \& Petty, J. W. (2010). Manajemen Keuangan: Prinsip dan Penerapan (10th ed., Vol. I). Jakarta: PT. Indeks.

Nuryanto, R., Tho'in, M., \& Wardani, H. K. (2014). Rasio Likuiditas, Rasio Solvabilitas, Rasio Rentabilitas Koperasi Jasa Keuangan Syariah Di Jawa Tengah. Jurnal Akuntansi dan Pajak, 15(01).

Riyanto. (2001). Dasar-Dasar Pembelajaran Perusahaan.Yogyakarta: BPFE.

Saidi. (2004). Faktor-Faktor Yang Mempengaruhi Struktur Modal Pada Perusahaan Manufaktur Go Public Di BEJ Tahun 1997-2002. Jurnal Bisnis dan Ekonomi.

Robert. (1997).Buku Pintar Pasar Modal Indonesia.Jakarta:Media Staff Indonesia.

Sartono. (2001). Manajemen Keuangan Teori dan Aplikasi (4th ed.).Yogyakarta: BPFE.

Sugiono. (2009). Manajemen Keuangan Untuk Praktisi Keuangan. Jakarta: Grasindo.

Soliha, E., dan Taswan. (2002). Pengaruh Kebijakan Hutang terhadap Nilai Perusahaan serta Beberapa Faktor yang Mempengaruhinya. Jurnal Bisnis dan Ekonomi, 9 (2).

Suad H. (2005). Dasar-Dasar Teori Portofolio dan Analisis Sekuritas. Edisi Keempat, UPP AMP YKPN, Yogyakarta.

Sudana. (2011). Manajemen Keuangan Perusahaan Teori dan Praktik. Jakarta: Erlangga

Sujoko, Soebiantoro. (2007). Pengaruh Struktur Kepemilikan Saham, Leverage, Faktor Intern dan Ekstern Terhadap Nilai Perusahaan. Jurnal Manajemen dan Kewirausahaan, IX.

Taswan (2003). Analisis Pengaruh Insider Ownership, Kebijakan Hutang dan Deviden Terhadap nilai Perusahaan serta Faktor-faktor yang Mempengaruhinya.

Tho'in, M., \& Prastiwi, I. E. (2019). An Analysis the Rupiah Exchange Rates Effect Against the American Dollar and Inflation Against the Growth of Islamic Banking Mudharabah Deposits in Indonesia. International Journal of Islamic Business and Economics (IJIBEC), 3(1), 82-91.

Tho'in, M. (2020). Profitability of Islamic Commercial Banks in Indonesia. MEC-J (Management and Economics Journal), 3(3), 277-288.

Yuliani. (2012). Determinan struktur modal pengaruhnya terhadap nilai perusahaan pada perusahaan yang sedang berkembang. Jurnal. Fakultas ekonomi sriwijaya.

Warsono. (2003). Manajemen Keuangan Perusahaan. Malang: Bayu media.

Wachowicz, J. M. (2001). Fundamental of Financia Management (12th ed.). (D.Fitriasari \& D. A. Kwary, Penerj.) Jakarta: Salemba Empat. 